\title{
Proenkephalin System in Human Polymorphonuclear Cells Production and Release of a Novel 1.0-kD Peptide Derived from Synenkephalin
}

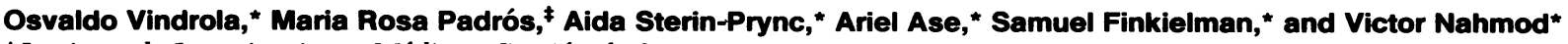
*Instituto de Investigaciones Médicas, Sección de Sustancias Vasoactivas, 1427 Buenos Aires, Argentina; and ${ }^{\ddagger}$ Hospital de Clinicas “José de San Martin," Immunogenética, 1120 Buenos Aires, Argentina

\begin{abstract}
In the hematopoietic system a pluripotent stem cell generates precursors for lymphoid and myeloid lineages. Proenkephalinderived peptides were previously detected in differentiated lymphoid cells. We have studied whether the proenkephalin system is expressed in a typical differentiated cell of the myeloid lineage, the neutrophil. Human peripheral polymorphonuclear cells contain and release proenkephalin-derived peptides. The opioid portion of proenkephalin (met-enkephalincontaining peptides) was incompletely processed, resulting in the absence of low molecular weight products. The nonopioid synenkephalin (proenkephalin 1-70) molecule was completely processed to a 1.0-kD peptide derived from the $\mathrm{COOH}$-terminal. This molecule was characterized in neutrophils by biochemical and immunocytochemical methods. The chemotactic peptide FMLP and the calcium ionophore A23187 induced the release of the proenkephalin-derived peptides, and this effect was potentiated by cytochalasin $B$. The materials secreted were similar to those present in the cell, although in the supernatant a higher proportion corresponded to more processed products. The 1.0-kD peptide was detected in human, bovine, and rat neutrophils, but the chromatographic pattern of synenkephalin-derived peptides suggests a differential posttranslational processing among species. These findings demonstrate the existence of the proenkephalin system in human neutrophils and the production and release of a novel 1.0-kD peptide derived from the synenkephalin molecule. The presence of opioid peptides in neutrophils suggests their participation in the inflammatory process, including a local analgesic effect. ( $J$. Clin. Invest. 1990. 86:531-537.) Key words: polymorphonuclear cell • proenkephalin system • synenkephalin-derived peptide
\end{abstract}

\section{Introduction}

Polymorphonuclear leukocytes play a major role in host defence against microbial infections (1-3) and are one of the primary mediators of the acute inflammatory response $(4,5)$. Basically, the neutrophil contains two distinct populations of secretory granules, the primary (azurophil) and the secondary (specific) granules (6). In addition, tertiary and quaternary granule populations have been suggested $(7,8)$, but with the

Address correspondence to Dr. Osvaldo Vindrola, Instituto de Investigaciones Médicas, Sección de Sustancias Vasoactivas, Donato Alvarez 3150, 1427 Buenos Aires, Argentina.

Received for publication 29 January 1990.

J. Clin. Invest.

(C) The American Society for Clinical Investigation, Inc.

0021-9738/90/08/531/07 \$2.00

Volume 86, August 1990, 531-537 possible exception of a distinct gelatinase-containing population (8), those granules and their contents have not been well defined.

Ligand binding to neutrophil surface receptors such as chemotactic peptides, C5a, and phorbol myristate acetate, as well as perturbation of the membrane with calcium ionophore A23187, have been shown to cause the release of the granular content (9-11).

Opioid peptides are involved in several events of the immune response $(12,13)$. These molecules induce changes on the activity of lymphocytes, macrophages, mast cells, and polymorphonuclear cells. On the other hand, opioid peptides may induce a local analgesic effect in acute inflammatory processes through the activation of peripheral receptors $(14,15)$. These studies have been mainly focused on peptides arising from the nervous system or endocrine glands.

The proenkephalin gene is expressed in cells of the nervous (16), reproductive (17), and hematopoietic (18) systems. In the latter, a pluripotent stem cell generated precursors for lymphoid and myeloid lineages. In this system proenkephalin-derived peptides were detected in differentiated lymphoid cells (18-20). Peripheral blood lymphocytes produced and released met-enkephalin and synenkephalin (proenkephalin 170) containing peptides when activated with a mitogenic agent (20).

In this work we have analyzed whether the proenkephalin system is expressed in one typical differentiated cell from myeloid lineage, the neutrophil. Production and release of metenkephalin- and synenkephalin-containing peptides induced by the chemotactic peptide FMLP and by calcium ionophore A23187 were studied. The production and release of a novel $1.0-\mathrm{kD}$ peptide derived from the synenkephalin molecule was detected.

\section{Methods}

Cell isolation. Human neutrophils were prepared from fresh blood samples $(100 \mathrm{ml})$ obtained from healthy volunteers. Neutrophils were purified by dextran sedimentation followed by centrifugation through a layer of Ficoll-Hypaque as described by Boyum (21). The granulocyte pellet was washed in saline, and the contaminating erythrocytes were eliminated by hypotonic shock. Preparations obtained in this manner contained $95 \%$ or more neutrophils. Cell viability was tested by the ability to exclude trypan blue.

Bovine neutrophils were purified from fresh blood $(250 \mathrm{ml})$ by differential centrifugation and a gradient of Ficoll-Hypaque (7), combined with the hypotonic lysis of contaminating erythrocytes. This preparation also contained $95 \%$ or more neutrophils.

Rat bone marrow cells were obtained from the femur. After cutting off the epiphyses, the marrow was extruded by forcing a cold salt solution through with a small needle and syringe. Cell clumps were broken up by repeated gentle aspiration through a 25-gauge hypodermic needle. Neutrophils from cell suspensions were isolated as described for human blood. 
Exocytosis experiments. $2 \times 10^{7}$ polymorphonuclear cells suspended in $1 \mathrm{ml}$ of Krebs Ringer phosphate (KRP), ${ }^{1}$ containing (in millimolar) $131 \mathrm{NaCl}, 5.2 \mathrm{KCl}, 1.3 \mathrm{MgSO}_{4}, 0.9 \mathrm{CaCl}_{2}$, and 15.7

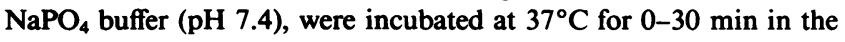
presence or absence of stimuli at the indicated concentrations. Incubation was terminated by rapid cooling on ice and centrifugation at $10,000 \mathrm{~g}$ for $5 \mathrm{~min}$. The cell-free supernatant was immediately incubated in boiling water for $15 \mathrm{~min}$. The pellet was stored at $-70^{\circ} \mathrm{C}$ until used. Cells that were treated with cytochalasin $B(5 \mu \mathrm{g} / \mathrm{ml})$ were preincubated with this agent for $5 \mathrm{~min}$ at $37^{\circ} \mathrm{C}$ before addition of the stimulus. The chemotactic peptide, FMLP, and calcium ionophore A23187 were used as exocytotic agents.

Total and free met-enkephalin assay. Frozen cells were resuspended in $1 \mathrm{M}$ acetic acid (pH 1.9 with $\mathrm{HCl}$ ), boiled for $15 \mathrm{~min}$, homogenized with a Polytron, and centrifuged at 50,000 $g$ for $1 \mathrm{~h}$. An aliquot of the supernatant was lyophilized and reconstituted in $50 \mathrm{mM}$ Tris-HCl buffer, $\mathrm{pH} 8.4$, and $2 \mathrm{mM} \mathrm{CaCl}_{2}$. An aliquot of the KRP supernatant of stimulated neutrophils was also diluted in the same Tris-HCl buffer. Free and total immunoreactive (IR) met-enkephalin, that is, before and after the sequential enzymatic digestion with trypsin and carboxypeptidase B (22), were determined by RIA (23).

Enkephalin and synenkephalin assay. Met-enkephalin and synenkephalin were determined by RIA as described previously $(23,24)$. Iodinated met-enkephalin and $\left[\mathrm{Tyr}^{63}\right]($ syn $63-70)$ synenkephalin were used as tracers. It was found that met-enkephalin antiserum crossreactivity was $100 \%$ with oxidized met-enkephalin, $0.3 \%$ with leu-enkephalin, and $<0.01 \%$ with met-enkephalin-Arg, dynorphin (1-13), and alpha, gamma, and beta endorphin. Sensitivity of the assay was $9 \mathrm{fmol}$; $\mathrm{IC}_{\text {s0 }}$ was $130 \mathrm{fmol}$. The antiserum to $\left[\mathrm{Tyr}^{63}\right]$ (syn 63-70) synenkephalin showed crossreactivity of $1 \%$ with native $8.6-\mathrm{kD}$ adrenal peptide (proenkephalin 1-77), which when digested with trypsin displayed a $20 \%$ crossreactivity, that reached $100 \%$ when completely digested with trypsin and carboxypeptidase B. No crossreactivity was observed with met-enkephalin, met-enkephalin-Arg, met-enkephalin-Arg-Phe, metenkephalin-Arg-Gly-Leu, leu-enkephalin, peptides $E$ and $F$, dynorphin B, amidorphin, and metorphamide. Sensitivity was $2 \mathrm{fmol} ; \mathrm{IC}_{50}$ was 50 fmol.

Gel filtration. Samples were applied to a column of Sephadex G-75 superfine $(63 \times 1.0 \mathrm{~cm})$ equilibrated with $1 \mathrm{M}$ acetic acid ( $\mathrm{pH} 1.9$ with $\mathrm{HCl}$ ). The column was eluted at a flow rate of $4 \mathrm{ml} / \mathrm{h}$ at room temperature. 2-ml fractions were collected, and aliquots were lyophilized and reconstituted in $50 \mathrm{mM}$ of Tris- $\mathrm{HCl}$ buffer, $\mathrm{pH} 8.4$, and $2 \mathrm{mM} \mathrm{CaCl}_{2}$. Before gel chromatography assay $10 \mathrm{mg}$ of bacitracin was added to each extract to reduce the nonspecific adsorption of proenkephalin-derived peptides. Eluates were monitored by ultraviolet (UV) absorbance $(280 \mathrm{~nm})$ and quantitation of $\mathrm{Na}^{+}$or $\mathrm{K}^{+}$ions to assess the reproducibility of the void and total volumes of the column.

A Sephadex G-50 superfine column $(60 \times 1.0 \mathrm{~cm})$ was equilibrated with $50 \%$ acetic acid and eluted at $10 \mathrm{ml} / \mathrm{h}$ at room temperature. 2.2-ml fractions were collected, and aliquots were lyophilized and reconstituted with Tris- $\mathrm{HCl}$ buffer.

HPLC chromatography. Samples were applied to a reverse phase column Ultropac, Lichrosorb RF18, $5 \mu \mathrm{m} ; 4 \times 250 \mathrm{~nm}$; LKB Instruments, Inc., Gaithersburg, MD). The column was preequilibrated with $50 \mathrm{mM} \mathrm{NaH} \mathrm{PO}_{4}$ containing $1 \mathrm{ml} / \mathrm{h}$ phosphoric acid and 5\% methanol. The elution was performed in acetonitrile gradient in the same buffer. The flow rate was $0.5 \mathrm{ml} / \mathrm{min}$ and $1-\mathrm{ml}$ fractions were collected, evaporated under an atmosphere of $\mathrm{N}_{2}$, and resuspended in RIA buffer.

Immunocytochemical assay. Drops of peripheral blood were applied to glass coverslips and incubated in a humidified chamber at $37^{\circ} \mathrm{C}$ for $90 \mathrm{~min}$. The coagulated materials were gently removed with a needle and glass-added cells were washed three times with $20 \mathrm{mM}$

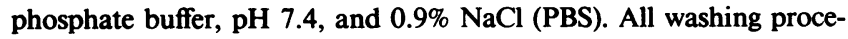
dures involved 5-min incubation with the buffer solution.

1. Abbreviations used in this paper: IR, immunoreactive; KRP, Krebs Ringer phosphate.
Cells were fixed with $3 \%$ glutaraldehyde in PBS for $60 \mathrm{~min}$ at $4^{\circ} \mathrm{C}$, washed three times in PBS, and immunocytochemically stained as follows: (a) Exhaust of endogenous peroxidase activity. Incubation in $3 \% \mathrm{H}_{2} \mathrm{O}_{2}$ (in ethanol) for $10 \mathrm{~min}$ at room temperature, then in $9 \%$ $\mathrm{H}_{2} \mathrm{O}_{2}$ (in anhydrous methanol) for $20 \mathrm{~min}$ at $4^{\circ} \mathrm{C}$; rinsed three times with PBS. (b) Incubation with primary antiserum against $\mathrm{COOH}-$ terminal synenkephalin-recognizing antiserum $(1: 200)$ in PBS with $0.01 \%$ BSA for $18 \mathrm{~h}$ at $4^{\circ} \mathrm{C}$; rinsed three times with PBS. (c) Incubation with peroxidase-labeled goat anti-rabbit IgG (1:50) in PBS-BSA buffer for $10 \mathrm{~min}$ at room temperature; washed three times with PBS. $(d)$ Incubation with diaminobenzidine and $\mathrm{H}_{2} \mathrm{O}_{2}$ as peroxidase reaction substrates for $5 \mathrm{~min}$ at room temperature. (e) Cells were finally stained with Giemsa for $5 \mathrm{~min}$ at room temperature.

\section{Results}

Human polymorphonuclear cells contain $53 \pm 5 \mathrm{pmol} / \mathrm{mg}$ protein $(n=10)$ of total immunoreactive met-enkephalin; nevertheless, free met-enkephalin molecule was not detected. The chromatographic profile of cell homogenate by Sephadex G-75 revealed the presence of high and intermediate molecular weight peptides displaying met-enkephalin immunoreactivity, and the absence of low molecular weight materials. IR synenkephalin was detected in products of high, intermediate, and low molecular weight. The IR met-enkephalin to IR synenkephalin ratio in materials of high and intermediate molecular weight, displaying both immunoreactivities, was between 6:1 and 3:1. Nevertheless, no strict correlation was observed in several other molecules (Fig. 1).

When the materials eluted in fractions 51-58 of the G-75 chromatography were applied to a G-50 column and analyzed for synenkephalin immunoreactivity, only one peak was observed in the position of $1.0 \mathrm{kD}\left[\mathrm{Tyr}^{63}\right](\mathrm{syn} 63-70)$ synenkephalin standard (Fig. $2 A$ ). The HPLC chromatography of this material also revealed the presence of one peak coinciding with the elution volume of [Tyr $\left.{ }^{63}\right]($ syn 63-70) synenkephalin (Fig. 2 B). IR met-enkephalin was also analyzed in G-50 and HPLC chromatography, but no immunoreactivity appeared in

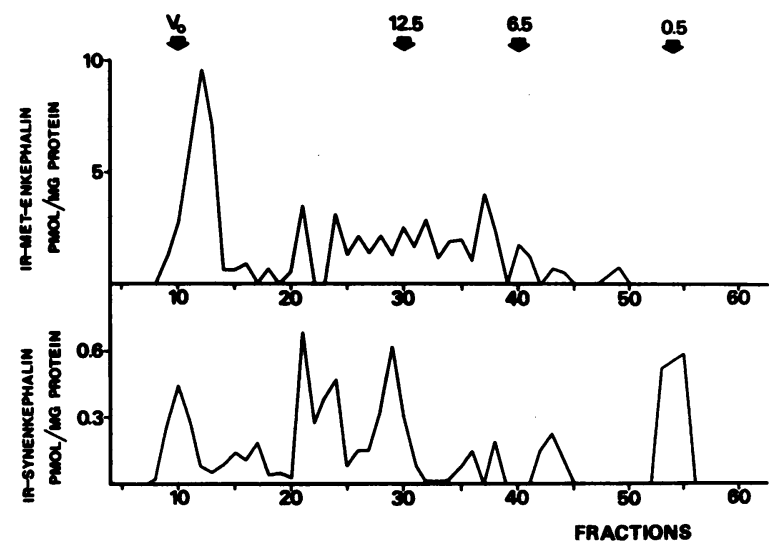

Figure 1. Sephadex G-75 chromatography of met-enkephalin- and synenkephalin-containing peptides from $1 \mathrm{M}$ acetic acid $(\mathrm{pH} 1.9$ with $\mathrm{HCl}$ ) extracts of $40 \times 10^{7}$ cells. The $50,000 \mathrm{~g}$ supernatant of the homogenate was applied to a $63 \times 1.0$ column and 2-ml fractions were collected. Aliquots of each fraction were lyophilized and resuspended in $50 \mathrm{mM}$ Tris-HCl buffer, $\mathrm{pH} 8.4$, and $2 \mathrm{mM} \mathrm{CaCl}_{2}$. Metenkephalin and synenkephalin immunoreactivity were assayed after sequential enzymatic digestion with trypsin and carboxipeptidase $B$. The elution positions of calibration markers were as follow: $V_{o}$, hemocyanin; $12.5 k D$, RNAse; $6.5 k D$, aprotinin; $0.5 k D$, enkephalin. 

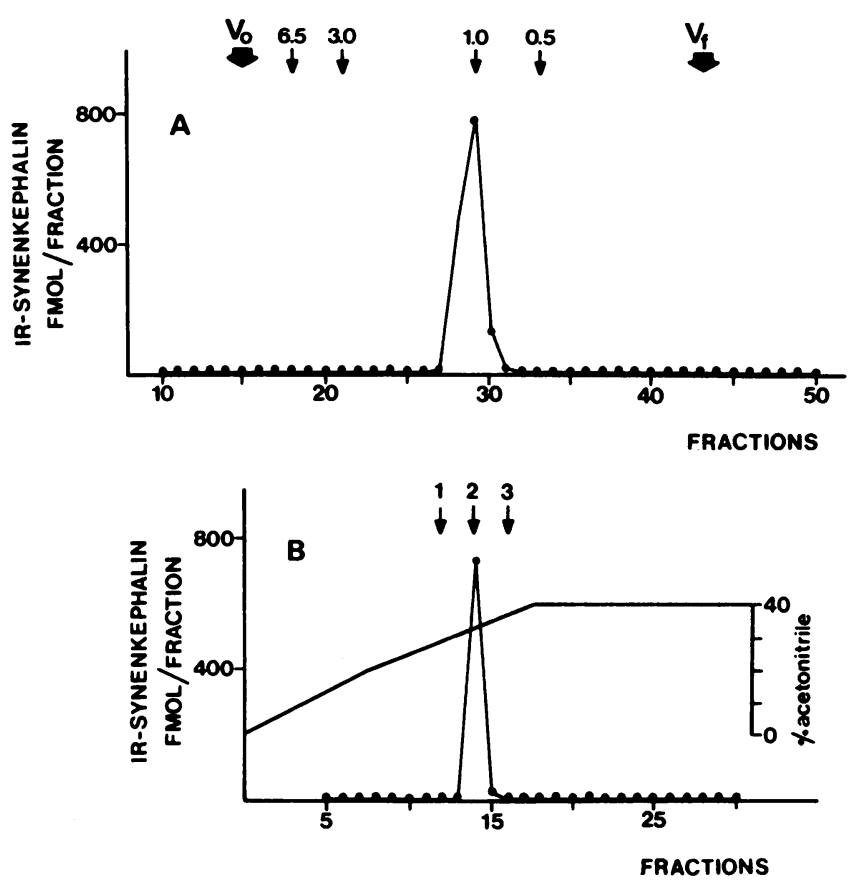

Figure 2. A, Aliquots of fractions corresponding to tubes 51-58 of G-75 were pooled, lyophilized, and resuspended in $50 \%$ acetic acid applied to a G-50 column, and 2.2-ml fractions were collected. Aliquots were lyophilized, resuspended in Tris- $\mathrm{HCl}$ buffer, and assayed for IR synenkephalin. The calibration markers were: $V_{o}$, hemocyanin; $6.5 k D$, aprotinin; $3.0 \mathrm{kD}$, amidorphin; $1.0 \mathrm{kD}$, [Tyr ${ }^{63}$ ](syn 63-70) synenkephalin; $0.5 k D$, leu-enkephalin; $V_{f}, \mathrm{NaCl}$. B, Aliquots of fractions eluted between tubes 27 and 31 of G-50 Sephadex were pooled, lyophilized, resuspended in $50 \mathrm{mM} \mathrm{NaH}_{2} \mathrm{PO}_{4}$ containing 1 $\mathrm{ml} /$ liter phosphoric acid and 5\% methanol, and applied to reverse phase HPLC. The elution was performed in acetonitrile gradient in the same buffer. The flow rate was $0.5 \mathrm{ml} / \mathrm{min}$ and $1-\mathrm{ml}$ fractions were collected, evaporated under an atmosphere of $\mathrm{N}_{2}$, resuspended in RIA buffer, and assayed for IR synenkephalin. Arrows indicate the elution position of standards: 1, Oxidized met-enkephalin; 2, [Tyr $\left.{ }^{63}\right]($ syn 63-70) synenkephalin; 3, met-enkephalin.

the position of the authentic pentapeptide or oxidized pentapeptide standard (data not shown).

The assay of crude polymorphonuclear cell homogenates by G-50 chromatography (Fig. 3) showed only one peak of IR synenkephalin, without enzymatic digestion, that was eluted in the position of the $1.0-\mathrm{kD}$ standard.

The immunocytochemical study demonstrated that a high proportion of peripheral human neutrophils stained with an antiserum, recognizing the $\mathrm{COOH}$-terminal sequence of synenkephalin. In addition, the cells presented different degrees of color intensities (Fig. 4).

Fresh isolated polymorphonuclear cells were incubated with different concentrations of the chemotactic peptide FMLP and the calcium ionophore A23187. The release of met-enkephalin-containing peptides was analyzed after several periods of stimulation (Fig. 5). Both exocytotic agents induced a concentration-dependent secretion of total IR met-enkephalin and the effect was enhanced by the previous cell incubation with cytochalasin B. 10 min of stimulation with $1 \mu \mathrm{M}$ of FMLP in the presence of cytochalasin B released $57 \%$ of the total IR met-enkephalin stored in resting human neutrophils. On the other hand, a 5-min exposure to $10 \mu \mathrm{M}$ of A23187 with

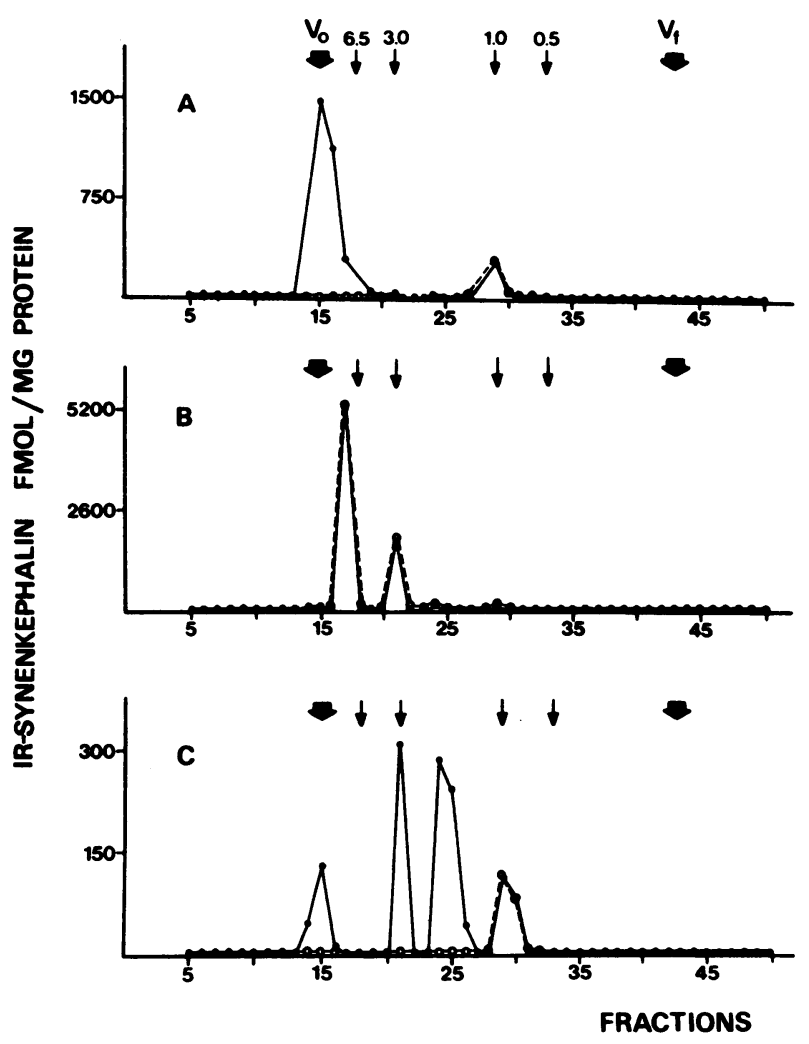

Figure 3. Sephadex G-50 chromatography of synenkephalin-containing peptides from human $(A)$, rat $(B)$, and bovine $(C)$ extracts of polymorphonuclear cells. Elution was performed as in Fig. $2 A$. Aliquots were lyophilized, resuspended in Tris-HCl buffer, and assayed for synenkephalin before (dotted line) and after (solid line) enzymatic digestion. The arrows indicate the position of calibration markers as in Fig. $2 A$.

cytochalasin B yielded $84 \%$ of the total peptide content of the cells.

IR met-enkephalin was detected in supernatants 2 min after stimulation of neutrophils with FMLP and calcium ionophore, reaching the highest values at 7 and $5 \mathrm{~min}$, respectively. When cells were previously incubated with cytochalasin $B$, the highest values for released peptides were found after 2 min of the stimulation with both exocytotic agents. A small secretion of met-enkephalin-containing peptides occurred in incubated but not stimulated polymorphonuclear cells, treated or not with cytochalasin B. In addition, the free met-enkephalin molecule was not detected in the supernatant of stimulated neutrophils.

The nature of met-enkephalin and synenkephalin-containing peptides in supernatants of FMLP-stimulated neutrophils, in the presence of cytochalasin B, was analyzed by G-75 chromatography (Fig. 6). Fractions from column eluates were assayed before and after the enzymatic digestion with trypsin and carboxypeptidase B. Proenkephalin-derived peptides of high, intermediate, and low molecular weight, displaying metenkephalin and synenkephalin immunoreactivity, were detected after enzymatic digestion. The chromatographic pattern was similar to that observed in resting neutrophils, although the supernatant showed higher concentrations of more processed materials. Without enzymatic digestion IR met-enkephalin and IR synenkephalin were mainly detected in frac- 

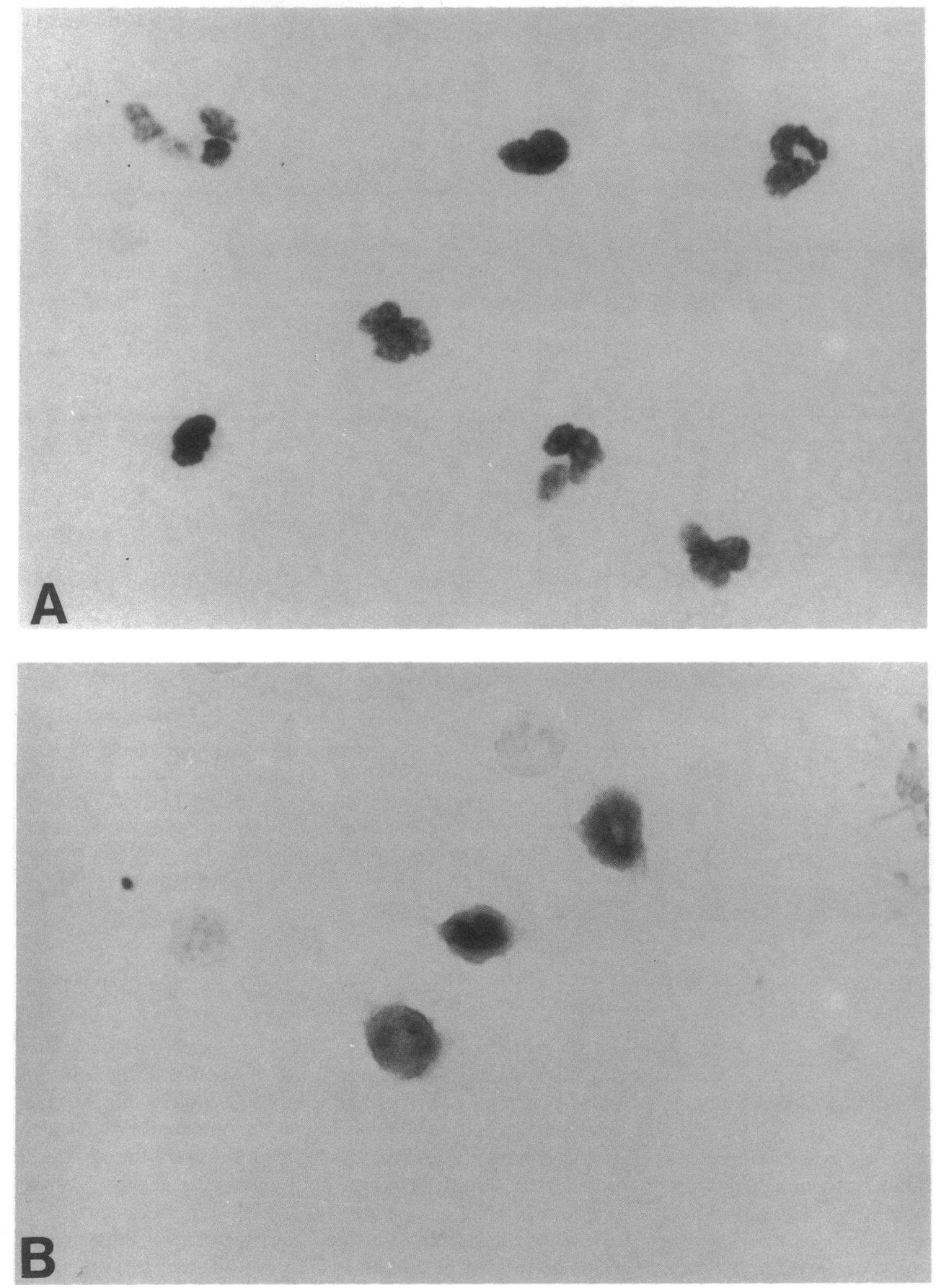

Figure 4. Immunoperoxidase staining of human polymorphonuclear cells incubated with nonimmune antiserum $(A)$ and $\mathrm{COOH}$ terminal synenkephalin-recognizing antiserum $(1: 200)(B)$. tions corresponding to peptides $<3-4 \mathrm{kD}$. The products eluted in fractions 50-57 displayed similar values when assayed with or without enzymatic digestion (Fig. 6).

When materials eluted in fractions 50-57 of the G-75 column were desalted by an Amberlite XAD-2 column and analyzed by HPLC chromatography, no IR met-enkephalin was observed in the position of met-enkephalin or oxidized metenkephalin. Nevertheless, a peak of synenkephalin IR material appeared in the position of $1.0-\mathrm{kD}\left[\mathrm{Tyr}^{63}\right](\operatorname{syn} 63-70)$ synenkephalin (Fig. 7).

To determine whether this $1.0-\mathrm{kD}$ peptide was also present in polymorphonuclear cells of other animal species, crude homogenates from human, bovine, and rat cells were analyzed by
G-50 chromatography (Fig. 3). The pattern by IR-synenkephalin products, without enzymatic digestion, from human and bovine neutrophils showed only a single peak eluted in fractions of the $1.0-\mathrm{kD}$ standard. On the other hand, rat neutrophils displayed four peaks coinciding with the 6.8-, 3.5-, 2.2and 1.0-kD molecular masses, where the two former molecules were 30-100 times more concentrated than the latter. The single peak in bovine and human cells and the four peaks in rat neutrophils had similar values with and without enzymatic digestion. The enzymatic treatment induced the appearance of additional IR synenkephalin in the void volume for rat neutrophils and several peaks higher than $1.0-\mathrm{kD}$ for bovine and human cells. In the latter cells higher concentrations of IR 


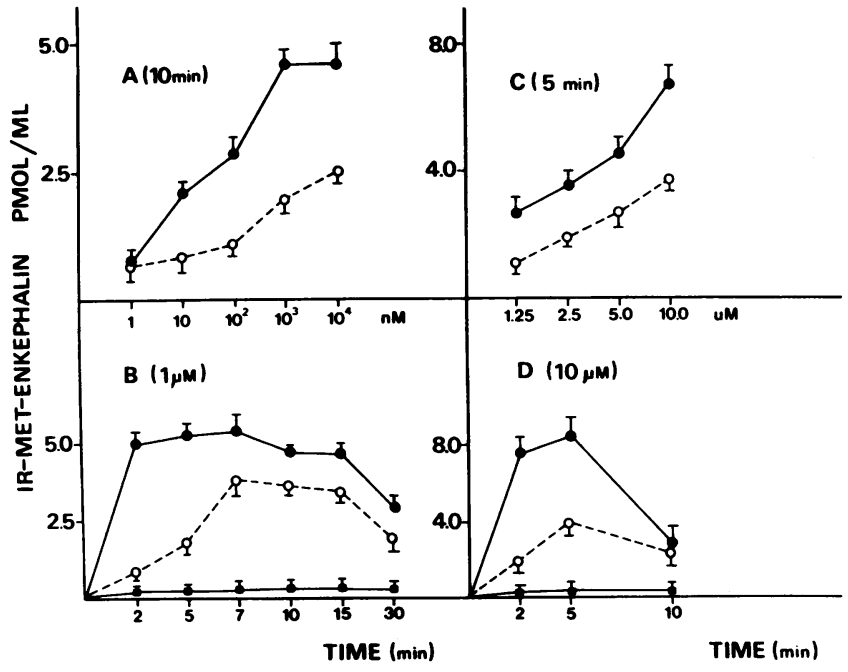

Figure 5. Release of IR met-enkephalin-containing peptides from stimulated human polymorphonuclear cells. $2 \times 10^{7}$ cells were incubated in $1 \mathrm{ml}$ of KRP buffer at $37^{\circ} \mathrm{C}$ and stimulated with the chemotactic peptide FMLP $(A, B)$ and the calcium ionophore A23187 ( $C$, $D)$. $₫$, Without stimulus; $O$, stimulus without cytochalasin B; •, stimulus with cytochalasin B. Met-enkephalin immunoreactivity was assayed after enzymatic digestion with trypsin and carboxypeptidase B. Results are mean + SEM of five experiments.

materials belonged to peptides $>6.5 \mathrm{kD}$, while in bovine cells they corresponded to peptides eluted at 3.5 and $2.2 \mathrm{kD}$.

\section{Discussion}

The present study demonstrated the existence of the proenkephalin system in human polymorphonuclear cells. The posttranslational processing of the opioid portion of the pre-

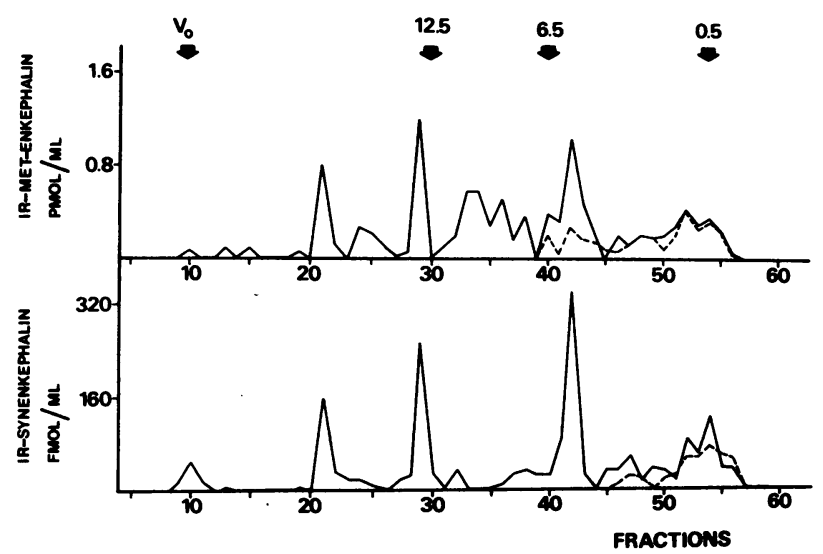

Figure 6. Sephadex G-75 chromatography of met-enkephalin- and synenkephalin-containing peptides released from stimulated polymorphonuclear cells. Pooled supernatants from 10 experiments, 2 $\times 10^{7}$ cells each, stimulated for $10 \mathrm{~min}$ with $1 \mu \mathrm{M}$ of FMLP in the presence of $5 \mu \mathrm{g} / \mathrm{ml}$ of cytochalasin $\mathrm{B}$, were lyophilized and resuspended in $2 \mathrm{ml}$ of $1 \mathrm{M}$ acetic acid (pH 1.9 with $\mathrm{HCl}$ ). Aliquots of eluted fractions were lyophilized and resuspended in Tris- $\mathrm{HCl}$ buffer. Met-enkephalin- and synenkephalin-containing peptides were assayed before (dotted line) and after (solid line) enzymatic digestion. The arrows indicate the positions of molecular weight markers as in Fig. 1.

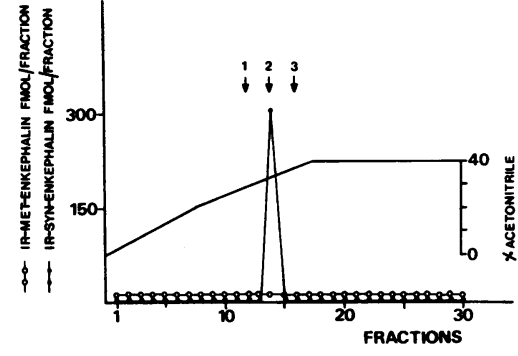

Figure 7. Aliquots of fractions eluted from tubes 50-57 were pooled, desalted by Amberlite XAD-2 column (which was eluted with $1 \mathrm{M} \mathrm{50 \%}$ acetic acid [pH 1.9 with $\mathrm{HCl}]$ : $50 \%$ acetonitrile), evaporated under an atmosphere of $\mathrm{N}_{2}$, and assayed by reverse phase HPLC as in Fig. $2 B$. Recuperation of ${ }^{125} \mathrm{I}$ $\left[\mathrm{Tyr}^{63}\right]$ (syn 63-70) synenkephalin and ${ }^{125} \mathrm{I}$-met-enkephalin by Amberlite column was $80-90 \%$ and $>90 \%$, respectively.

cursor molecule may be incomplete due to the absence of low molecular weight peptides. Nevertheless, the nonopioid synenkephalin (proenkephalin 1-70) molecule (25) was completely processed to a $1.0-\mathrm{kD}$ peptide derived from the $\mathrm{COOH}$ terminus. Incomplete processing of the opioid portion of proenkephalin was also observed in other tissues and cells as rat heart ventricle and spermatids and several cell lines of human neuroblastoma (26-28). Although the synenkephalin molecule (proenkephalin 1-70) may act as a signal-recognizing molecule to target proenkephalin into regulated secretory granule (29), the intact molecule was released from stimulated bovine hypothalamus (30).

Polymorphonuclear cells synthesized peptides of high and intermediate molecular weight containing both the met-enkephalin and synenkephalin sequences in ratios according to those predicted for proenkephalin-derived peptides (31). Nevertheless, other materials of high and intermediate molecular weight displayed only met-enkephalin immunoreactivity. These molecules were also detected previously in the rat striatum (32). Synenkephalin-containing peptides were always associated with the presence of met-enkephalin except for the 1.0-kD peptide, which presented the COOH-terminal sequence of the free synenkephalin molecule. These results suggest that an early event may involve the cleavage at the monobasic residue in position 62 of proenkephalin, followed by rupture at the dibasic residue Lys-Arg in position 71 . The presence of the 1.0-kD synenkephalin-derived peptide was demonstrated by biochemical and immunocytochemical methods.

A high percentage of peripheral polymorphonuclear cells displayed positive immunostaining for synenkephalin, however some variability in color intensity was observed. These findings may be explained by the fact that peripheral neutrophils represented a heterogenous population of cells (4).

Chemotactic stimuli have been shown to cause the selective release of the content of specific and gelatinase granules, while azurophil granules are retained unless cells are pretreated with cytochalasin B $(9,10)$. We demonstrated that FMLP and calcium ionophore A23187 induced the release of met-enkephalin-containing peptides without pretreatment with cytochalasin B. The highest secretion of peptides was reached after $7 \mathrm{~min}$ with a $1-\mu \mathrm{M}$ FMLP treatment and after 5 min with $10 \mu \mathrm{M}$ of $\mathrm{A} 23187$. Under these conditions the released peptides represented 47 and $50 \%$, respectively, of the total IR met-enkephalin stored in resting neutrophils. Accordingly, the proenkephalin system may behave like gelatinase granules in the human neutrophil (8). 
Cytochalasin B enhanced the effect of FMLP and A23187 on IR met-enkephalin secretion and also shortened the time elapsed to reach the highest values, suggesting that proenkephalin-containing granules are associated to the microfilament system (4).

Proenkephalin-derived peptides released from neutrophils stimulated with FMLP in the presence of cytochalasin B were similar to those present in the cell, although a higher proportion of more processed materials was detected. The supernatant contained the completely processed $1.0-\mathrm{kD}$ peptide derived from synenkephalin and incompletely processed materials containing the met-enkephalin sequence. Free met-enkephalin production was not observed in the extracellular space, but met-enkephalin-containing peptides were readily degraded. These results may be related to the elevated activity of met-enkephalin catabolizing enzymes in neutrophil membranes (33). Physiological studies report that under specific stimulus, intermediate molecular weight peptides derived from proenkephalin may be released to the plasma (34). In addition, plasmatic processing of precursor to low molecular weight molecules was also reported (35). On the other hand, intermediate products in the processing of proenkephalin have been shown to display specific opioid activity (36).

Considering that the neutrophil is a typical cell of regulated secretion (37), where the role of the cytoskeleton in granule transport is well known (38), and where it is possible to induce the specific release of different populations of granules $(9,10)$, it seems proper for this cell to be used as a model to study the mechanism of neuropeptide secretion.

Bovine and rat polymorphonuclear cells produced synenkephalin-derived peptides; nevertheless, quantitative and qualitative differences were observed between these species. The 1.0-kD peptide appeared in the three neutrophil populations, but while in bovine and human cells this peptide was the only one presenting free the $\mathrm{COOH}$ terminus of synenkephalin, four molecules with this characteristic were observed in rat neutrophils. These findings suggest a differential posttranslational processing of proenkephalin in rat neutrophils when compared with bovine and human cells. Differences between bovine and human neutrophils may be related to changes in the processing rate: both cells displayed a similar chromatographic pattern differing only in the concentration of each peptide.

The opioid peptides are involved in several events of the immune response $(12,13)$. Proenkephalin-, proopiomelanocortin-, and prodynorphin-derived peptides have been reported to induce changes in lymphocyte, monocyte, mast-cell, and neutrophil activities $(12,13)$. Opioid peptides may also be involved in the inflammatory process, inducing local analgesic effects in inflamed areas. It has been suggested that peptides originating from nervous terminals or from the general circulation after their secretion by endocrine glands may mediate this effect (15).

Neutrophils have the potential to modulate almost any aspect of inflammation, which means that in some conditions the secretory products of the neutrophil, in addition to their proinflammatory activities, may dampen or even terminate it (4). An autocrine, paracrine, and endocrine role of neutrophils in inflammation has been suggested. Our results suggest that proenkephalin-derived peptides may participate in the inflammatory process, and the neutrophil may behave like a peddler who delivers analgesics door to door, that is, to sensitive nerve terminals in the local inflammatory process.

The biological role of the $1.0-\mathrm{kD}$ peptide derived from the synenkephalin molecule in the inflammatory process and in the cascade of the immune response events remains to be discerned.

\section{Acknowledgments}

We thank Dr. Patricia Miranda and Dr. Jorge Teson for their valious collaboration, and Dr. Jean Rossier for the donation of the synenkephalin antiserum.

This work was supported by grants from CONICET (Argentina).

\section{References}

1. Klebanoff, S. J., and C. B. Hamon. 1972. Role of myeloperoxidase mediated anti-microbial systems in intact leucocytes. J. Reticuloendothel. Soc. 12:170-196.

2. Arnold, R. R., M. F. Cole, and J. R. McChee. 1966. Bactericidal effect for human lactoferrin. Science (Wash. DC). 197:283-290.

3. DeDuve, C., and R. Wattiaux. 1966. Function of lysosomes. Annu. Rev. Physiol. 28:435-460.

4. Segal, A. W., and P. Venge. 1984. The neutrophil in inflammation. In Inflammation, Basic Mechanisms, Tissue Injuring Principles, and Clinical Models. P. Venge and A. Lindbom, editors. Almqvist \& Wiksell Periodical Company, Stockholm, Sweden.

5. Weissmann, G., H. M. Korchak, H. D. Perez, J. E. Smolen, I. M. Goldstein, and Hofftein. 1979. Leukocytes as secretory organs of inflammation. Adv. Inflammation Res. 1:95-112.

6. Bainton, D. F., and M. G. Farquhar. 1968. Differences in enzyme content of azurophil and specific granules of polymorphonuclear leukocytes. II. Cytochemistry and electron microscopy of bone marrow cells. J. Cell Biol. 39:299-317.

7. Gennaro, R., B. Dewald, U. Horisberger, H. U. Gubler, and M. Baggiolini. 1983. A novel type of cytoplasmic granule in bovine neutrophils. J. Cell Biol. 96:1631-1661.

8. Dewald, B., U. Bretz, and M. Baggiolini. 1982. Release of gelatinase from a novel secretory compartment of human neutrophils. $J$. Clin. Invest. 70:518-525.

9. Henson, P. M., M. H. Ginsberg, and D. C. Morrison. 1978. Mechanisms of mediator release by inflammatory cells. In Membrane Fusion. G. Poste and G. L. Nicolson, editors. Elsevier Science Publishing Co., Inc. New York. 407-508.

10. Wright, D. G., D. A. Bralove, and J. I. Gallin. 1977. The differential mobilization of human neutrophil granules. Am. J. Pathol. 87:273-281.

11. Kaplan, H. B., H. S. Edelson, F. Friedman, and G. Weissmann. 1982. The roles of degranulation and superoxide anion generation in neutrophil aggregation. Biochim. Biophys. Acta. 721:55-63.

12. Sibinga, N. E. S., and A. Goldstein. 1988. Opioid peptides and opioid receptors in cells of the immune system. Annu. Rev. Immunol. 6:219-249.

13. Morley, J. E., N. E. Kay, G. F. Solomon, and N. P. Plotnikoff. 1987. Neuropeptides: conductions of the immune orchestra. Life Sci. 41:527-544.

14. Joris, J. L., R. Dubner, and K. M. Hargreaves. 1987. Opioid analgesia at peripheral sites: a target for opioids released during stress and inflammation. Anesth. Analg. 66:1277-1281.

15. Stein, C., M. J. Millan, T. S. Shiffenberg, P. Klaus, and A. Herz. 1989. Peripheral opioid receptors mediating antinociception in inflammation: evidence for involvement of mu, delta and kappa receptors. $J$. Pharmacol. Exp. Ther. 248:1269-1275.

16. Douglass, J., O. Civelli, and E. Herbert. 1984. Polyprotein gene expression: generation of diversity of neuroendocrine peptides. Annu. Rev. Biochem. 53:665-715. 
17. Kilpatrick, D. L., R. D. Howells, N. Noe, C. L. Bailey, and S. Udenfriend. 1985. Expression of preproenkephalin like mRNA and its peptide products in mammalian testis and ovary. Proc. Natl. Acad. Sci. USA. 82:7467-7469.

18. Zurawski, G., M. Benedik, B. J. Kamb, J. S. Abrams, S. M. Zurawski, and F. D. Lee. 1986. Activation of mouse T-helper cells induces abundant preproenkephalin mRNA synthesis. Science (Wash. DC). 232:772-775.

19. Moustein, H. J., R. Kolkesson, and L. Terenius. 1986. Proenkephalin A-like in human leukemia and CNS-tissues. Life Sci. 39:2237-2241.

20. Padrós, M. R., O. Vindrola, P. Zunszain, L. Fainboin, S. Finkielman, and V. Nahmod. 1989. Mitogenic activation of the human lymphocytes induce the release of proenkephalin derived peptides. Life Sci. 45:1805-1811.

21. Boyum, A. 1976. Isolation of lymphocytes, granulocytes and macrophages. Scand. J. Immunol. 5:9-15.

22. Vindrola, O., A. Ase, S. Finkielman, and V. E. Nahmod. 1988. Differential release of enkephalin and enkephalin containing peptides from perfused cat adrenal glands. J. Neurochem. 50:424-430.

23. Vindrola, O., M. Asai, M. Zubieta, E. Talavera, E. Rodriguez, and G. Linares. 1984. Pentylentetrazol kindling produces a long-lasting elevation of IR-met-enkephalin but not IR-leu-enkephalin in rat brain. Brain Res. 297:121-125.

24. Chaminade, M., W. K. Stell, and J. Rossier. 1989. Detection of synenkephalin by antisera directed against it carboxil terminus. In Second Forum on Peptides. A. Aubry, M. Maarand, and B. Vitoux, editors. John Libbey Eurotext Limited, Montrouge, France. 174:121124.

25. Liston, D. R., J. J. Vanderhaeghen, and J. Rossier. 1983. Presence in brain of synenkephalin a proenkephalin-immunoreactive protein which does not contain enkephalin. Nature (Lond.). 302:62-65.

26. Howells, R. D., D. L. Kilpatrick, L. C. Bailey, M. Noe, and S. Udenfriend. Proenkephalin mRNA in rat heart. 83:1960-1963.

27. Yoshikaura, K., and T. Aizawa. 1988. Enkephalin precursor gene expression in postmeiotic germ cells. Biochem. Biophys. Res. Commun. 151:664-671.
28. Folkesson, R., H. J. Moustein, T. Geiger, S. Pahlman, K. Nilsson, and $\mathrm{L}$. Terenius. 1988. Expression of the proenkephalin gene in human neuroblastome cell lines. Brain Res. 427:147-154.

29. Ase, A., O. Vindrola, R. Aloyz, M. T. Rodriguez Vida, S. Finkielman, and V. E. Nahmod. 1989. Association of endogenous synenkephalin containing peptides with intracellular membranes of bovine adrenal medulla. Biochem. Biophys. Res. Commun. 158:790796.

30. Liston, D., and J. Rossier. 1984. Synenkephalin is correleased with met-enkephalin from neuronal terminals in vitro. Neurosci. Lett. 48:211-216.

31. Meeters, K. M., and J. Rossier. 1987. Affinity purification of synenkephalin-containing peptides including a novel 23.3 kiloddalton species. J. Neurochem. 49:721-728.

32. Vindrola, O., R. Aloyz, A. Ase, F. Saravia, S. Finkielman, and V. E. Nahmod. 1988. Differential association of proenkephalin derived peptides with microsomal membranes of adrenal, heart and rat brain. PAABS (Pan-Am. Assoc. Biochem. Soc.) Symp. 5:201. (Abstr.)

33. Fischer, E. G., and N. E. Folke. 1987. Interaction of metenkephalin with human granulocytes. Ann. NY Acad. Sci. 496:146-150.

34. Watson, J. D., J. G. Varley, S. J. Tenilin, S. Mellbak, L. H. Rees, and C. J. Hinds. 1988. Biochemical characterization of circulating met-enkephalins in canine endotoxin shock. J. Endocrinol. 111:329-334.

35. Metters, K. M., J. Rossier, J. Paquin, M. Chretien, and N. G. Seidah. 1988. Selective cleavage of proenkephalin-derived peptides (<23,300 Daltons) by plasma kallikrein. J. Biol. Chem. 263:1254312553.

36. Hollt, V. 1986. Opioid peptide processing and receptor selectivity. Annu. Rev. Pharmacol. Toxicol. 26:59-77.

37. Burgess, T. L., and R. B. Kelly. 1987. Constitutive and regulated secretion of proteins. Annu. Rev. Cell Biol. 3:243-293.

38. Jesaitis, A. J., J. O. Tolley, and R. A. Allen. 1986. Receptor-cytoskeleton interactions and membrane traffic may regulate chemoattractant-induced superoxide production in human granulocytes. $J$. Biol. Chem. 261:13662-13669. 